\title{
WILLIAM SQUIRE KENYON AND THE IOWA SENATORIAL ELECTION OF 1911
}

\author{
By E. Daniel Potts
}

A former resident of Calhoun County, Mr. Potts became involved with Iowa political history while working on his $M$. A. thesis at the University of Iowa ten years ago. He later did his doctorate in Modern History at Oxford University. He is currently inaugurating a program in United States history at Monash University, Melbourne, Australia.

In 1846 the General Assembly of the newly admitted State of Iowa met-rather excitedly, one would think-to elect its first two United States Senators. However, Whig and Democratic forces in the Assembly were so evenly matched that Iowa had to wait two years for her Senators. In an anti-climax, the Democrats succeeded in electing Augustus Caesar Dodge of Burlington and George Wallace Jones of Dubuque to the Senate. ${ }^{1}$ By 1911 this indirect method of electing Senators, which had proved troublesome from the start, was fortunately considered archaic. This was the last time that the General Assembly was to choose a Senator without the benefit of at least a preferential primary. ${ }^{2}$

In the 1850 's the Republican party had gained control of

${ }^{1}$ Ruth A. Gallaher, "Deadlock on Senators," The Palimpset, 8 (January, 1947), 1.

${ }^{2}$ Upon the urging of Governor Albert Baird Cummins, a direct primary law, providing for the nomination of state officers by party primaries in which every registered voter took part, and for the choice of a party's senatorial candidate at the same primary election, was passed by the Assembly in 1907. Under its terms Republican and Democratic Assemblymen were morally, though not legally, obliged to cast their votes for the senatorial candidate who had received the most votes in the "preferential primary." For discussion of the events leading to this law see Emory H. English, "Evolution in Iowa Voting Practices," Annals of Iowa, XXIX (April, 1948), 249-89; and William L. Bowers, "The Fruits of Iowa Progressivism, 1800-1900," Iowa Journal of History, LVII (January, $1959), 46-50$. In the primary of June 2, 1908, the first in which this law was tested, Senator William Boyd Allison defeated Governor Cummins by a vote of 105,891 to 95,256 . Later in 1908, following Allison's death, Cummins easily defeated John F. Lacey in a second primary. On November 24 a special session of the Assembly ratified the results by duly electing Cummins. 
most State offices and had continued, with occasional exceptions, to dominate its politics. This virtual one-party system naturally created a susceptibility for intra-party strife. Strife that was minor, however, when compared with the great schism within both the State and National parties in the first part of this century. The Republicans, even in 1911, did not seriously need to fear being defeated by the Democrats, but they did fear that party divisions might thrust victory into their opposition's hands. At this time the two major factions of the Republican party were the Old Guard Standpatters led by Governor Beryl F. Carroll (and previously by Senator Allison until his death in 1908) and the Progressives led in Iowa by "insurgent" Senator Cummins.

The 1911 election clearly reveals (1) the conditions which had already lead to the adoption of the preferential primary system in Iowa and other states (and which were to lead, in 1913, to the ratification of the 17th Amendment providing for the direct election of all United States Senators); (2) the extent of the Standpat-Progressive split; (3) the extent of equally, if not more, important divisions among the Progressives themselves; and (4) the reasons the leading Iowa Progressives were unwilling, in 1912, to bolt the Republican party and throw in their fortunes with the Progressives and Theodore Roosevelt.

Cummins' election as Governor in 1901 had given Iowa Progressives their first great victory. Twice re-elected Governor Cummins and his numerous supporters saw to it that "many of the aims of Progressivism were realized." ${ }^{3}$ His election to the Senate in 1908 boosted both the state and national movements. Senior Senator Dolliver, though a moderate Progressive himself, had opposed Cummins when the latter ran against Allison in the June, 1908 primary. At Cummins' later victory, the two were reconciled and, as Dolliver's biographer writes, were "ready to fight as allies for the policies in which they believed, policies to which they hoped William Howard Taft was committed."4

${ }^{3}$ Bowers, "The Fruits of Iowa Progressivism, 1900-1915,” 34-60.

${ }^{4}$ Thomas R. Ross, Jonathan Prentiss Dolliver: A Study in Political Integrity and Independence (Iowa City, 1958), 224-31. 
However, by 1910 it became evident that Taft was not committed, at least in their view, to these policies, so the two Senators joined Robert La Follette of Wisconsin, Albert Beveridge of Indiana, and other Progressives in the Insurgent movement.

On October 15, fifty-three year old Dolliver died unexpectedly at his home in Fort Dodge, and his death caught Iowa's politicians, Standpatter and Progressive alike, offbalance. All were in a turmoil at the thought of who would be his successor. The general election for State offices due on November 8 allowed less than a month to arrange for a preferential primary. Divisive tendencies within Iowa Republicanism had for some time created the possibility that during the election many rank and file would vote for the Progressive candidate in their county, be he Democrat or Republican. ${ }^{5}$ However, the realization that the General Assembly would have the responsibility of selecting a new U.S. Senator, with or without the benefit of a primary, temporarily closed Republican ranks and led to the return of Standpat Governor Carroll together with 104, out of a possible 158, Republican legislators.

In the meantime, speculation over possible candidates for Dolliver's seat had started to arouse interest in Dolliver's protege and fellow townsman, William Squire Kenyon. Prosecuting Attorney of Webster County from 1892 to 1896 and District Judge of the 11th Judicial District from 1900 to 1902 , Kenyon seemed to some an unlikely choice. He had had little personal experience in politics and, at a time when true Progressives strongly opposed the railroads (which had controlled Iowa's Republican politics during the latter part of the nineteenth century), he had accepted appointments as district attorney (1904) and general attorney (1907) for the Illinois Central. On the other hand, earlier in 1910 Dolliver's recommendation had induced President Taft, who at this time was trying to moderate the anger of the Insurgents, to appoint Kenyon to serve under Attorney-General Wickersham as a special prosecutor of anti-trust suits. His activities in this field were receiving statewide publicity, but he was still not as

${ }^{5}$ Fort Dodge Messenger, October 21, 1910, 11. 


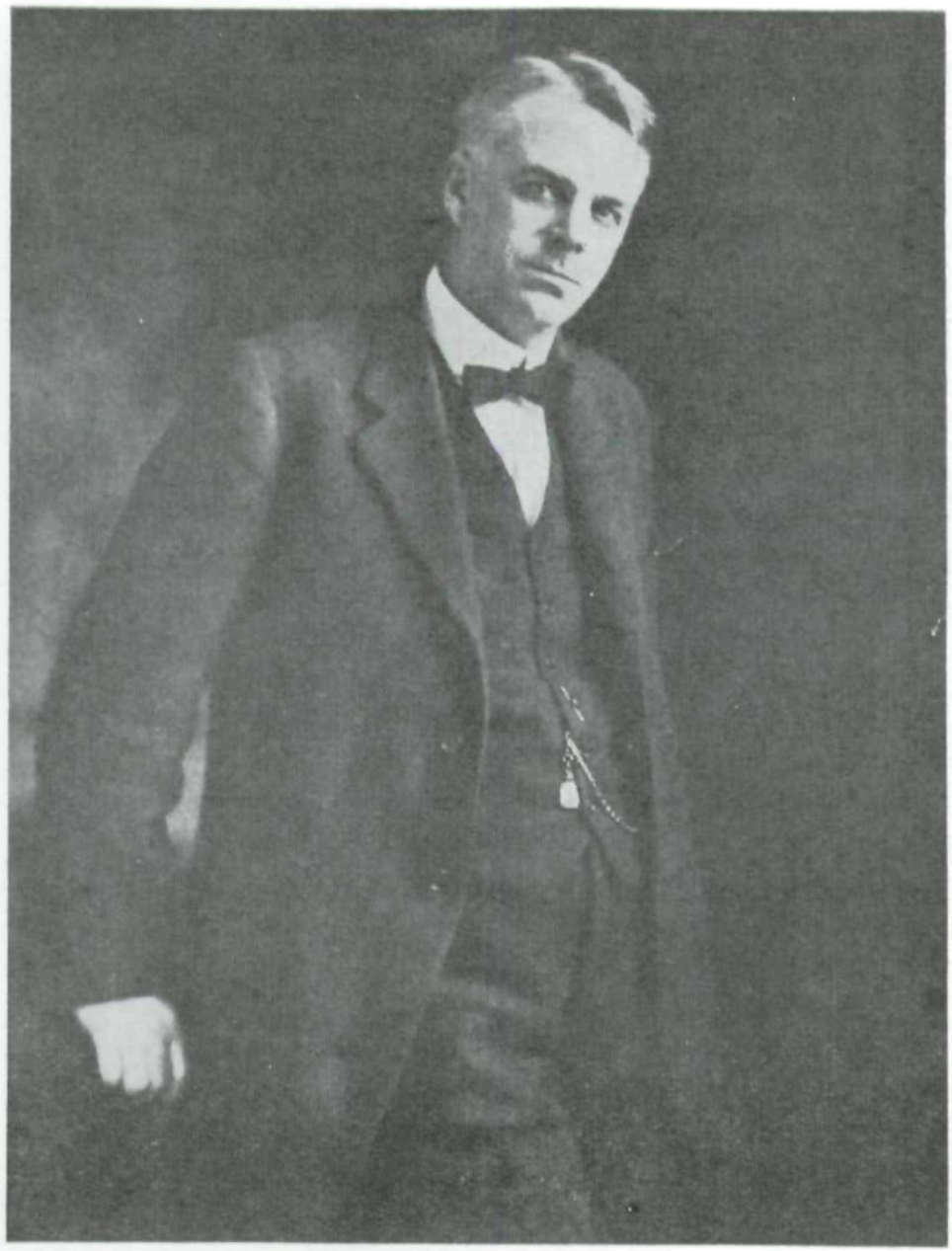

William SQuire Kenyon

well known as his major opponents. ${ }^{6}$ In the long run this might have proved an advantage. As many knew him but slightly, they had little cause to dislike him.

${ }^{6}$ Des Moines Register and Leader, October 25, 1910. Kenyon did not, as Dolliver's biographer states, practice law and engage in politics in Iowa from the time he received the advice to do so from Dolliver on December 20, 1907, until his own election to the Senate. Ross, Jonathan Prentiss Dolliver, 342. 
The leading figure among the old-line Progressives was initially Abraham B. Funk, a veteran of many political battles and a close friend of Cummins. State Senator Funk, editor of the Spirit Lake Beacon, together with another early Cummins supporter named Howard W. Byers, provided the main Progressive opposition to Kenyon. When speculation began as to who would replace Dolliver many believed that one of these men would receive Cummins' backing. This, it was thought, would "be powerful in determining the choice of his colleague by the legislature. ..."

The Congressman from Council Bluffs, Walter I. Smith, had perhaps the strongest position of the Standpatters. On October 21 , however, Smith renounced any moves on his behalf; ${ }^{8}$ as had George Perkins of Sioux City, another veteran Standpatter. Governor Carroll was also considered. Some political observers thought that if re-elected by a sufficient margin, Carroll might put his own name before the General Assembly. ${ }^{9}$ Finally, there was La Fayette Young, editor of the State's main Standpat organ, the Des Moines Capital. Young, who soon emerged as the Standpat candidate, firmly believed that the G.O.P. was itself the only true Progressive party, and regarded any deviator from its policies as little better than a traitor.

A week after Dolliver's death, newspapers throughout Iowa began to sing the praises of their factional or regional favorite. Oddly enough, a Fort Dodge Democratic paper was the first to acclaim "that locally all citizens, irrespective of party, have joined as one man in support of Judge Kenyon."10 The Progressive Messenger soon took up the refrain, drawing attention away from Kenyon's politically disadvantageous railroad connections by pointing out his anti-trust activities. ${ }^{11}$ More importantly still, Harvey Ingham's Des Moines Register and Leader suggested as a compromise between the Standpat and Progressive factions the logic of choosing a candidate like Kenyon, who was both a Progressive and a member of

${ }^{7}$ Fort Dodge Messenger, October 17, 1910, 1.

${ }^{8}$ Des Moines Register and Leader, October 22, 1910, 1.

${ }^{9} \mathrm{He}$ was re-elected, but received only $49.8 \%$ of the popular vote.

${ }^{10}$ Fort Dodge Daily Chronicle, October 22, 1910, 1.

${ }^{11}$ Fort Dodge Messenger, October 27, 1910, 4. 
President Taft's administration. ${ }^{12}$ As still another newspaper put it: "He is in line with the political sentiment of Iowa, though not offensively partisan or factional in his make up." ${ }^{13}$ Kenyon himself was noncommittal, refusing at this stage to declare openly his candidacy. ${ }^{14}$

The excitement of finding candidates did not completely blind politicians to the importance that the method used to select Dolliver's replacement would have in the success or failure of their particular choice. The Democrats realized that they would have more chance of winning a primary than a majority of the seats in the Assembly, so they declared on October 22 that:

Iowa should be represented in the senate by a man who represents the people, and ... we should all join in requesting ... . Governor Carroll to follow the precedent established at the time of the death of Senator Allison under conditions very similar to the present ... nothing should stand in the way of the selection of a candidate who is the choice of the people of the whole state. ${ }^{15}$

The divided Republican leaders were quick to question both the parallel and the proposal. According to the law, a special session of the General Assembly would first have to approve the holding of a primary. Some stated that, with the general election less than three weeks away, there was not enough time for this. Some Republicans who believed that the law committed the State to the de facto election of Senators by the voters found themselves supporting the Democrats. ${ }^{16}$

But a primary was not held. Immediately after his own re-election on November 8, Carroll ended speculation about whom he would appoint to the Senate pending the meeting of the Assembly by naming LaFayette Young. Progressives cried "corrupt bargain":

In political circles it is generally believed that Governor Carroll will have, or already has had, an understanding with Colonel Young .... that the latter shall not be a candidate for the

${ }^{12}$ Des Moines Register and Leader, October 22, 1910, 1.

${ }^{13}$ Boone News-Republican, quoted in Fort Dodge Messenger, October 26, 1910, 1.

${ }^{14}$ Des Moines Register and Leader, October 28, 1910, 1.

${ }^{15}$ Des Moines Register and Leader, October 22, 1910, 2.

${ }^{16}$ Ibid., 1 . 
senatorship in the primaries eighteen months from now. . . It is considered certain that Governor Carroll himself will enter the lists as the standpat candidate for the junior senatorship. ${ }^{17}$

However that might have been, Young's appointment undoubtedly was meant to, and did, give the Standpatters a temporary advantage. They advocated that all Republicans support Young in the interests of party harmony. But party harmony did not appear to be a likely outcome of the scramble for the office which now began in earnest. There were so many starters that some questioned:

How long will it take to eliminate the Lilliputians in the senatorial race? Where do these small bore politicians get their nerve, anyway? . . . In considering the question, legislators will do well to ask themselves, "What chance would this candidate have if his case were submitted to the . . . voters of the state?". . . The legislators ought to select a man whose candidacy will be ratified at the primaries of $1912 .{ }^{18}$

Not unnaturally Young was the first formally to announce his availability. Asking the Assembly to sustain Carroll's choice, his Capital claimed that Young, as a proponent of "constructive" government, should be classed as a Progressive. After listing his "progressive actions ... . in the State Legislature, through his paper, and as a private citizen" the Capital concluded: "a man who does everything for the public which he is called on to do and contributes annually thousands of dollars for good causes, ought not to be called a reactionary."

Progressives, including Kenyon, appeared more reluctant to commit themselves. Many were obviously still waiting for evidence of Cummins' favor before throwing their hats into the ring. Finally, on November 30, he spoke out. He called for the election of a Progressive, but disappointed Funk and Byers-possibly because he could not have pleased both-by refusing to be specific. He favored someone "who had established a title as a progressive Republican in the struggles of the last few years."

${ }^{17}$ Fort Dodge Messenger, November 12, 1910, 1. The Young MSS. in the State Department of History and Archives do not reveal anything on this subject.

${ }^{18}$ Knoxville Journal, quoted in Fort Dodge Daily Chronicle, December $8,1910,4$. In the 1912 primary Kenyon received 190,349 votes to 124,583 for Young and 65,766 for Claude Porter, the Democratic candidate.

${ }^{19}$ Des Moines Capital, November 22, 1910, 1.

${ }^{20}$ Des Moines Register and Leader, December 2, 1910, 1. 
Had Cummins chosen to elaborate this might have excluded Kenyon-as by inference it did. As he did not, State Representative Frederic Larrabee of Fort Dodge announced Kenyon's ambitions. ${ }^{21}$ On the same day (December 5) a Byers supporter as expected opened the Cummins Progressive attack on Kenyon by declaring that "Real progressives are not developed from railroad attorneys." ${ }^{22}$ Kenyon was hopefully attacked as a favorite-son candidate whose strength would soon shift to Byers. "While conceding Kenyon's qualifications" the Atlantic Telegraph thought that there was ". . . a general and growing belief all over the state that the two men to fight out the factional differences in the Republican party are Web Byers and Laff Young. Other candidates simply befog the issues. . . ." ${ }^{23}$ Young's Capital professed to agree, but contrarily centered its criticism on Kenyon. ${ }^{24}$ Clearly both old-line Progressives and Standpatters secretly recognized him as a most powerful opponent.

Answering the allies' (i.e. Cummins' Progressives) charge that Kenyon did not qualify as a Progressive, the Mason City Times declared that he was "in fact more radical and emphatic in his political beliefs than several of the prominent progressives whose names have been associated with the senatorship." ${ }^{25}$ The Standpat Cedar Rapids Republican followed the lead of the more perceptive Register and Leader in looking on Kenyon as a compromise who, although "more radical" than they would like, was "a sincere and able man" with no "bombast and demagogism" in him. ${ }^{26}$

Meanwhile, Senator Young had joined the Democrats in reviving the call for a preferential primary:

${ }^{21}$ Fort Dodge Daily Chronicle, December 9, 1910, 1.

${ }^{22}$ Webster City Herald, quoted in Fort Dodge Messenger, December $6,1910,4$. The Herald, as the Messenger was quick to point out, ignored the fact that Cummins himself had at one time been a railroad attorney, as had that "most distinctive progressive" Attorney-General Byers who had become a candidate three days earlier.

${ }^{23}$ Atlantic Telegraph, quoted in Fort Dodge Chronicle, December 14, $1910,4$.

${ }^{24}$ Des Moines Capital, December 23, 1910, 1.

${ }^{25}$ Mason City Times, quoted in Des Moines Register and Leader, January 1, 1911, 1.

${ }^{26}$ Cedar Rapids Republican, quoted in Fort Dodge Messenger, December $23,1910,4$. 
I respectfully ask the Republican party in pursuance of its late policy to order a special primary for the purpose of naming the successor ... to Senator Dolliver. I believe the masses of the party are anxious to have an opportunity to express themselves. Such opportunities should be given to them. ${ }^{27}$

A primary would allow hope for the Standpatters who could profit from splits in progressive ranks. The Progressives, well aware of their dissensions, ridiculed Young, who had opposed the primary law in 1907, for switching his position. Actually, however, they themselves were the ones open to ridicule. They had always supported the principle of primaries but when internal strife placed them at a disadvantage they talked of the expense, and argued that the results would not be representative because the Iowa winter would keep so many voters away from the polls!

When on January 9 the 34th General Assembly of the State of Iowa convened, the Progressives' strength was still badly fractured among the supporters of Kenyon, Funk, Byers, and a host of "Lilliputians." The Standpatters had united behind Young, and the Democrats behind Claude Porter of Centerville. As the first senatorial ballot was not to be taken until January 16, various bills calling for a primary were introduced, but all failed. It now seemed certain that the legislature would have the full responsibility for electing a Senator. Some of the more far-sighted expected a hard and drawn-out battle in the weeks ahead; they were not disappointed.

As January 16 approached, managers for the various candidates worked feverishly to gain and hold pledges of support. Bargains of the "you support my bill and I'll support your candidate" type were undoubtedly made. ${ }^{28}$ However, politicians were all anxious to avoid scandal. All were wary of a repetition of the events which had already led to the well publicized Lorimer Case in Illinois. ${ }^{29}$ Young declared loudly that his

${ }^{27}$ Quoted in Des Moines Capital, December 24, 1910, 11.

${ }^{28}$ Interview with Emory H. English, November 24, 1955. English, Editor of the Annals of Iowa at the time of the interview, was active in progressive politics during this period. A member of the General Assembly from 1902 to 1906 , he was State Printer in 1911. For more detail on this subject, see [Emory English] "Senator Kenyon-An Idealist," Annals of Iowa, XXXI (April, 1952), 313-16.

${ }^{29}$ William Lorimer was elected to the Senate by the Illinois Legislature in June, 1909. After the investigation into his election was com- 
only campaign expenditures would be for the cost of a room for his headquarters and the price of an occasional cigar for a friend. ${ }^{30}$ Kenyon was even more virtuous-"If I am elected Senator ... there will be no strings tied to me. . . . I will absolutely make no promises whatsoever regarding patronage or future political favors. ${ }^{31}$

The first ballot, held in separate conventions of each House, solved nothing. Of the 104 Republicans, 33 voted for Young; Kenyon led the Progressives with 22; Funk gained 21; and the remainder of the votes were shared by Byers and minor contenders. On the next day the Assembly cast its first joint ballot. The results were basically the same. Day after day balloting continued-one ballot per day-but no important change became evident until February 10, when Funk withdrew in favor of former Governor Warren Garst of Coon Rapids in hope that his "loyal supporters" would contribute as best they could "to the quickest and best possible solution" of the deadlock. ${ }^{32}$ As Byers had already withdrawn in favor of Funk, the field of major Republican entrants was now down to three. When Garst gained most of Funk's supporters the Standpatters confidently expected Kenyon eventually to withdraw-leaving the field open for Young. When he failed to oblige, his and Young's managers met; but as a contemporary observed the next year, "the spirit of compromise and concession was just not present." ${ }^{33}$

Senator Leslie Francis (Fun's campaign-manager) forty years afterwards vividly characterized three of the Republicans who daily cast their ballots. Of Joe Allen of Pocahontas, Francis wrote that "The most determined bulldog had nothing on old Joe when it came to sticking tight. To him Kenyon owed his success more than to any combination of others. . . .

pleted, the Senate (on July 13, 1912) adopted a Resolution declaring "that corrupt methods and practices were employed in his election, and that the election, therefore, was invalid." Biographical Directory of the American Congress, 1774-1961 (Washington, D. C., 1961), 1235.

${ }^{30}$ Des Moines Capital, November 22, 1910, 1.

${ }^{31}$ Quoted in H. E. Kershner, William Squire Kenyon and the KenyonDuncombe-William-Squire Family Histories (New York, 1935), 88.

${ }^{32}$ Quoted in Des Moines Capital, February 11, 1911, 1.

${ }^{33}$ Dan E. Clark, History of the Senatorial Elections in Iowa (Iowa City, 1912), 258-60. 
a big, jovial fellow from the broad prairies of norwest Iowa. ... He seemed to be in agreement with the other fellow but never to the extent of changing his mind." ${ }^{34}$ Captain John D. Brown of Decatur, a firm Standpat Senator who was later to become Commander of the Iowa G.A.R., was described as being ". . . a gentleman of even greater firmness of purpose. ... he permitted all to share with him his knowledge that all Progressives were illegitimate offspring of the devil!" ${ }^{35}$ Then, on the other hand, there were men like Cady Chase of Hamilton County whose "opinions varied from day to day. His natural course was opposition to whatever ought to be advocated by others. . . . He was sometimes a Standpatter, at other times a Progressive, but denied that he was either, and insisted that he was independent of all ties. ${ }^{36}$

When it seemed clear that Kenyon would not withdraw, Young unexpectedly dropped out of the race. The Standpatters, however, unwilling to favor an "illegitimate offspring of the devil," threw their support instead to Horace Deemer of Council Bluffs. Deemer, who was to be backed by a majority of Standpatters to the end, was a State Supreme Court Justice. His views, like those of Kenyon, were not very well known, though he was thought to be more sympathetic to Progressive policies than Young. ${ }^{37}$ Obviously, the Standpatters hoped that Deemer would sway enough Progressive voters to ensure his election. And he almost succeeded. On his first ballot, he gained 47 votes, one more than Kenyon. That Deemer, rather than Kenyon, received the support of the allies (who had been backing Garst) illustrates the bitterness between Cummins and Kenyon Progressives. Many observers believed that enough Kenyon men would break ranks to achieve vic-

${ }^{34}$ Leslie Francis, "The Last Legislative Election of an Iowa United States Senator," Annals of Iowa, XXXI (April, 1952), 270.

${ }^{35}$ Ibid., 270-271.

${ }^{36}$ Ibid., 271.

${ }^{37}$ Strangely enough, in two others states (Montana and New York) in the same year, state supreme court justices had won election to the Senate, breaking long senatorial deadlocks-these men were Henry Lee Myers (1862-1943) in Montana and James A. O'Gorman (1860-1943) in New York. In 1909 Dolliver and other members of the Congressional delegation from Iowa had unsuccessfully urged President Taft to appoint Judge Deemer to a vacancy on the Supreme Court. Ross, Jonathan Prentiss Dolliver, 269. 
tory for Deemer. Not all were as determined as Joe Allen!

However, they had not anticipated a hastily arranged ad hoc coalition between Kenyon Progressives and Democrats which stopped the Deemer band-wagon. A motion had been made for a second ballot to be held later the same day, but the coalition blocked it because the "joint convention was ready for a stampede to the compromise candidate." ${ }^{38}$ It was "clever politics for . .. [ [the Democrats] . . . to continue the fight between the two republican ranks" in hope that the impasse would lead to a primary which would allow their candidate some chance of success. ${ }^{39}$

From this time to the last day of the session the fight was one between Deemer and Kenyon, Garst receiving only a handful of votes. Gradually Kenyon won over almost universal Progressive support, with the notable exception of those from Deemer's 9th Congressional District. ${ }^{40}$ Neither seemed near victory until March 16 when, on the 43rd ballot, Kenyon reached a high of 65 votes-13 short of the number required. Six Standpatters, including three of their "steering committee," had broken ranks. The Capital was now sure that this was his "'last card,' as politicians say be cannot receive another vote." ${ }^{\prime 1}$ Young pleaded with the Standpats to hold firm in order to:

prevent an election.... and ... put the senatorship into the hands of the people. This the standpatters can do by keeping their heads and standing with their time-tried leaders. The people of Iowa want to settle the senatorship in their own way at the ballot box. ${ }^{42}$

An increase of four more votes on the next ballot encouraged Kenyon's supporters to attempt a motion for another roll-call that day. Somewhat ironically, this motion was defeated by a Standpat-Democrat coalition. No further change

${ }^{38}$ Des Moines Capital, February 16, 1911, 8.

${ }^{39}$ Ibid.

${ }^{40}$ This is a good example of how legislatures would vote for a sectional candidate regardless of the Republican faction to which they belonged. The 9th District at this time included Adair, Audubon, Cass, Guthrie, Harrison, Mills, Montgomery, Pottawattamie (Council Bluffs), and Shelby counties. In the 1912 primaries Kenyon received 9,241 votes in this district, compared to Young's 6,807 .

${ }^{41}$ Des Moines Capital, March 17, 1911, 4.

${ }^{42}$ Quoted in Des Moines Register and Leader, March 17, 1911, 1. 
resulted for a score more ballots, when on Tuesday, April 11perhaps in desperation, as the General Assembly was to adjourn on the morrow-a motion was passed providing for a special joint convention to continue voting until an election resulted. This motion was short-lived. Immediately following the next voting (the 66th), the Democrats supported a Standpat motion, which passed by a margin of two (79-77), to end that day's session.

On April 12 the convention met for the last time. Most observers had given up hope of success but "There was everywhere an atmosphere of uncertainty ... the galleries ... were filled with an eager, expectant throng." ${ }^{\prime 3}$ As the clerk proceeded at noon to call the roll, "Intense silence pervaded the chamber ... silence of the kind you have often read about when it is said if a pin should drop on the floor you could hear it." ${ }^{44}$ The first name called was that of Standpat Adams of Fayette County. "Everyone felt instinctively [that this] would mark the beginning of a break in the direction of Judge Kenyon, and . . . might easily develop into a stampede." On the grounds that it was the duty of the Assembly to elect a Senator, Adams dramatically voted for Kenyon. ${ }^{45}$ His vote was expected to turn the tide. It did not. Though Kenyon made a few more gains, ${ }^{46}$ at the end he was still shy of two votes. When asked to rule on the question of changing allegiance, Lieutenant-Governor Clarke, Chairman of the Convention, immediately replied that votes could be changed at any time prior to the official announcement of the results.

Groups of Kenyon supporters surrounded stiff-necked standpatters and begged and pleaded with them to come into the fold before it was everlastingly too late. But the recalcitrant

${ }^{43}$ Des Moines Register and Leader, April 13, 1911, 1.

${ }^{44}$ Ibid.

${ }^{45}$ Ibid.

${ }^{46}$ Including one Democrat, who on the previous day had switched from Porter to Kenyon. Representative Linnan of Pocahontas claimed that a majority of his constituents, regardless of party, were for Kenyon and that he felt it to be his duty, for a Democrat could not be elected to support Kenyon. His claim was verified in 1912, when Kenyon received 1,301 votes in this county, compared to 299 for Young and 379 for Porter. 
brethren looked down or far away and shook their heads. The scene reminded one of the big revival meetings like Bill Sunday's where devoted workers labor so persistently with stubborn sinners. ${ }^{47}$

At a motion for yet another roll-call, a humorous note was added by one of those "stubborn sinners"-none other than Captain Brown-who "rose and bellowed with great intensity that traitors to the cause of decency in government might abandon Judge Deemer and slink over to enjoy the loaves and fishes,' but as for him he 'would stay right there and vote for principle and right until hell froze over.' " 48

Fortunately this was not necessary. The motion passed, and balloting started anew - proceeding without change from Adams to Zeller. At the end, however, two Progressives who had hitherto sided with Deemer finally reconsidered their votes. Seven more followed suit, and the deadlock was broken. Kenyon was officially declared elected to the United States Senate. ${ }^{49}$

Why at the last possible moment did the 9th District Progressives who had favored Deemer switch to Kenyon? In 1955, Emory English, one of the few survivors of the active political battles of this period, and himself a Cummins supporter, remembered hearing of a telegram from Cummins asking the Deemer Progressives to vote for Kenyon on the last ballot. ${ }^{50}$ There are at least two other possible explanations. First, Republican opponents of Kenyon could have feared being labelled obstructionists. Secondly, they might have had the mistaken-as it turned out-hope that the real senatorial contest would take place during the 1912 primaries.

${ }^{47}$ Des Moines Register and Leader, April 13, 1911, 1.

${ }^{48}$ Francis, "The Last Legislative Election of an Iowa United States Senator," 211.

${ }^{49}$ Kenyon served in the Senate until February, 1922, when he resigned to accept an appointment as Judge of the Eighth Circuit of the U. S. Circuit Court of Appeals. He held this office, refusing an appointment as Secretary of Navy in 1924, until his death on September 9, 1933. While a Circuit Judge he served as a member of the Wickersham Commission on the enforcement of prohibition.

${ }^{50}$ Interview cited in footnote 28. Another long-term survivor of the period, Thomas J. Bray, gave some of its flavor in his book of reminiscences called Rebirth of Freedom (Indianola, Iowa, 1957). 
Newspapers throughout the state were effusive in their praise of the new Senator. The Register and Leader thought:

It . . . well worth all the contest to get a man of real inspiration in the seat of Dolliver. There are men enough in Washington of wealth and social and business standing, but there are not enough men who know the needs of the people and who are willing to take off their coats and get into the squabble for what Roosevelt has called the square deal. By birth, by early education, by hard struggle, by constant association, Judge Kenyon has come to know the problems of the average man. His ambitions have never led him away from the ideas of his youth. His public and private career are a vindication of his early-formed purpose to be of some benefit to those who struggle and aspire..$^{11}$

Regionalism or sectionalism in Iowa is a factor whichoften talked about but seldom explained-must be examined to understand the early twentieth century political history of that State. Republican legislators (and one Democrat) voted for a man because he was from their own part of the State. Throughout the contest, and especially after Kenyon's Progressive opponents withdrew, he received almost universal support of the 10th and 11th District Republicans, while Deemer until the very last ballot held equal loyalty from the 9th District counties. ${ }^{52}$

Principles, both Progressive and Standpat, were often discussed during the long deadlock, but it is doubtful whether they influenced greatly Kenyon's supporters and the successful outcome. If anything, the election shows that few Standpatters or Progressives would, like Captain Brown, stand by their principles "until hell froze over." The failure of any sizeable group of Progressives to encourage moves for a primary, and the sudden turn-about of the Standpatters in favor

${ }^{51}$ Des Moines Register and Leader, April 13, 1911, 6.

${ }^{52}$ In the ballot on March 1, 1911, for instance, Kenyon received all but one of the 31 votes from the Republicans representing the 10th and 11th Districts. Deemer, on the other hand, received total support from the eight Republicans from the 9th District. The 10th District comprised Boone, Calhoun, Carroll, Crawford, Emmet (Estherville), Hamilton, Hancock, Humboldt, Kossuth, Palo Alto, Pocahontas, Webster (Fort Dodge), and Winnebago counties; the 11th-Buena Vista, Cherokee, Clay, Dickinson (Spirit Lake), Ida, Lyon, Monona, O’Brien, Osceola, Plymouth, Sac, Sioux, and Woodbury (Sioux City) counties. In the 1912 primaries Kenyon received 34,306 votes in these two districts, compared to 12,292 for Young. 
of a primary, indicate that Progressive reforms would receive support only when convenient.

The battle over, the election of Kenyon culminated a long Progressive v. Standpat contest for control of Iowa's Republican party, the Progressive victory resulting in a very temporary decline of "Standpatism." More significantly, perhaps, this election revealed a split in Progressive ranks totally unrelated to the far better known schism on the national level between the followers of Robert M. La Follette and those of Theodore Roosevelt. As time passed, this split between the progressive Republican forces ${ }^{53}$ in Iowa was to widen still further, with resulting Democratic or Standpat victories in both state and national elections.

In 1912 Iowa cast its thirteen electoral votes for Woodrow Wilson, the first Democrat to take the State since Franklin Pierce in $1852 .{ }^{54}$ Although Roosevelt's Progressives were obviously stronger than the regular Republicans $(32.8 \%$ v. $24.4 \%$ of the total vote), Kenyon and Cummins alike, while favoring Roosevelt over Taft, elected to stay within the Republican party organization. It is possible, perhaps even probable, that with their more active help Roosevelt would have carried Iowa. And, if the pattern had been repeated in other states where Progressives dominated the Republican party, a viable and long-lasting Progressive party might well have replaced the Republicans as one of America's two major political organizations. ${ }^{55}$

Why, at least in Iowa, did powerful Progressive leaders refuse to shift their allegiance? The answer, it is suggested, is not because they were annoyed at the way Roosevelt had usurped La Follette's position as the national Progressive leader-nor because they distrusted Roosevelt's brand of Progressivism, which in Kenyon's case at least was closer to his

${ }^{53}$ For a detailed analysis of these groups see the Author's "A Comparative Study of the Leadership of Republican Factions in Iowa, 19041914," M. A. Thesis, State University of Iowa, 1956.

${ }^{54}$ Wilson, however, received only $37.65 \%$ of the popular vote.

${ }^{55}$ Governor Herbert Hadley of Missouri, and Senators Borah of Idaho, Bourne of Oregon, and Crawford of South Dakota were only a few of the influential Progressives who refused, as did Senators Kenyon and Cummins, to join the third party movement. 
own than La Follette's. It was because influential Progressives in the State had, in and before 1911, already won control of the Republican party, and they were unwilling to risk losing it either to the Standpatters or to another Progressive faction.

\title{
ONE HUNDRED AND NINETY DAYS IN REBEL PRISONS
}

\author{
By William H. Allen \\ Co. G., 17th Iowa Vet. Vol. Infantry
}

William H. Allen came with his family from Ohio to settle at Knoxville, Iowa, in the early 1850's. He enlisted April 10, 1862, at the age of 18 in the 17th Iowa Volunteer Infantry, composed of 10 companies and totaling 958 men. The famed 17th Iowa fought at the battles of Corinth, Iuka, and Jackson (Vicksburg Campaign) before it was ordered to Memphis as part of Sherman's Army. In December of 1863, the 17th marched to Huntsville, Alabama, where it spent the winter and spring guarding large supply trains. In April of 1864, the majority of the regiment re-enlisted as "Veteran Volunteers." Of the number of men who had started from Keokuk two years earlier, 352 were left remaining for duty. The 17th Iowa was just about to join the main army at the front, when it was separated from the 1st Brigade and orderd to return to Tilton, Georgia, where it arrived in July, 1864. Here it was assigned to the duty of guarding the railroad between Dalton and Resaca, a distance of fifteen miles.

Private Allen's account of prison life during the Civil War (which was written from memory after a lapse of thirty-four years) begins with that October morning in 1864 when the 17th Iowa found itself hopelessly surrounded by a largely superior force of the enemy.

On a bright October morning down at Tilton, Georgia, the 17th Iowa was doing garrison duty. We had been there since about the first of July, 1864, guarding the railroad from Chat- 
Copyright of Annals of Iowa is the property of State of Iowa, by \& through the State Historical Society of Iowa and its content may not be copied or emailed to multiple sites or posted to a listserv without the copyright holder's express written permission. However, users may print, download, or email articles for individual use. 